\title{
Vurdering av ny medisinsk teknologi
}

\author{
Prosedyrene og premissene ved evaluering av nytt medisinskteknisk \\ utstyr ivaretar ikke helsevesenets behov, eksemplifisert ved den sene \\ innføring av positronemisjonstomografi (PET) i Norge.
}

Det er rimelig at ny og kostbar teknologi underkastes granskning før introduksjon og generell bruk. Men det er viktig at premissene for vurdering blir gjennomgått kritisk, spesielt når det kan reises tvil om hvorvidt analyse av fra 2004 (3) av åtte PET-studier fra perioden 1997-2003. Hybridteknologien PET/CT, som er blitt en realitet etter dette, kan selvfølgelig ikke bedømmes ut i fra slike gamle, ikke-representative data.

\section{«Vi mener at Kunnskapssenteret mangler forståelse for at diagnostiske metoder i rask utvikling ikke passer inn i deres evalueringsverktøy.»}

konklusjonen er berettiget. Introduksjonen av positronemisjonstomografi (PET)

i Norge ble utsatt i flere år med henvisning til to vurderinger fra Senter for medisinsk metodevurdering (det nåværende Kunnskapssenteret) $(1,2)$. Vi ser i dag utarbeiding av nasjonale retningslinjer for kreft som representerer den samme grunnleggende holdning. Konklusjoner baseres på systematiske oversikter og metaanalyser av randomiserte, kontrollerte studier, uten vektlegging av annen kunnskap.

Problemstillingen illustreres av følgende mellomkonklusjon i den første SMM-rapporten (1): «Den diagnostiske nøyaktighet er god sammenlignet med alternativer, for initial stadieinndeling av NSCLC, samt å oppdage mediastinale lymfeknutemetastaser og fjernmetastaser ved denne kreftformen. [...] Det er ingen dokumentasjon på noen klinisk nytteverdi. Det kan ha sammenheng med det generelt dårlige kliniske utfall av denne sykdommen.» Logikken er egentlig at det ikke er meningsfylt å utrede lungekreft, da målet med utredning er å påvise spredning til lymfeknuter og fjernmetastaser og utfallet da er dårlig! Har man en bedre metode for å påvise slike, så kan man diskutere de økonomiske aspekter, men ikke rettferdiggjøring av selve metoden.

Oppdaterte nasjonale retningslinjer for diagnostikk, behandling og oppfølging av flere kreftformer er under utarbeiding, og Kunnskapssenteret er behjelpelig med dokumentasjon, blant annet med følgende utkast om oesophaguskreft: «Undersøkelser med PET har ikke bedret diagnostikken ved øsofaguskanser, og i en metaanalyse har man ikke kunnet dokumentere bedret staging av pasienten.» Grunnlaget er en meta-
Man bør derfor ta nye initiativ og inkludere nye, større enkeltpubliseringer. I flere nye studier, f.eks. Meyers og medarbeideres (4), fremgår det at det hos $5 \%$ av pasienter med oesophaguskreft påvises uventede fjernmetastaser ved PET/CT, i tillegg til spredning til flere lymfeknutestasjoner. Dette har betydning i forhold til de meget store inngrep disse pasientene skal gjennomgå.

Det ble i årene 1999-2002 utført en rekke kunnskapsbaserte metodevurderinger av PET i land som er medlemmer av International Association of Health Technology Assessment (INAHTA). Til tross for at de benyttet de samme artikler og evalueringsverktøy, kom de til vidt forskjellige konklusjoner og anbefalinger. En kritisk lederskribent kommenterer dette slik (5): «If one were to take a scientific approach to this outcome, the reports would either be characterised as fraud or the methodology would be called useless and abandoned very quickly.»

Den danske rapporten, som konkluderte som den norske, møtte betydelig motstand. Sundhedsstyrelsen opprettet en ny faggruppe og fikk utarbeidet en ny rapport i 2002 (6). Denne anbefalte en omfattende utbygging av PET i Danmark, der det i dag er 18 PET-maskiner og seks syklotroner.

Styreformann i INATHA besvarte lederen med et leserbrev (7). Det ble poengtert at den første rapporten fra Danmark ikke var en full gjennomgang og vektlagt at ekspertgruppen som skrev den godkjente litteraturgjennomgangen. Det ble også konkludert med at den første rapporten ikke var i konflikt med neste rapport. Slik vi ser det, er nettopp dette svakheten. Premissene for disse rapportene kan endres fra gang til gang og fra land til land, og det er bestemmende for utfallet. $\mathrm{Og}$ da er verdien begrenset.

Vi mener at Kunnskapssenteret mangler forståelse for at diagnostiske metoder i rask utvikling ikke passer inn i deres evalueringsverktøy. Nye diagnostiske metoder som gir inkrementell verdi i stadieinndeling blir i liten grad utsatt for randomiserte studier, da målsettingene med slik bildediagnostikk er riktig stadieinndeling. Og har man en bedre undersøkelse tilgjengelig, brukes den.

Vi har nå fått PET/CT i Norge. Når neste teknologisprang kommer, bør helsevesenet være på offensiven og forlange at de som utreder fremtidens diagnostiske metoder tenker nytt.

\section{Tore Bach-Gansmo}

ingolv.tore.bach-gansmo@helse-bergen.no

Senter for nukleærmedisin/PET

Haukeland universitetssykehus

5021 Bergen

og

Institutt for kirurgiske fag

Universitetet i Bergen

Trond Velde Bogsrud

Avdeling for nukleærmedisn

Rikshospitalet

Oppgitte interessekonflikter: Ingen

\section{Litteratur}

1. Smiseth OA, Myhre ES, Aas M et al. SMM report 8/2000. Positron emission tomography (PET). Oslo: Senter for Medisinsk Metodevurdering, 2000.

2. Mørland B. SMM-rapport 6/2003. PET-diagnostikk og klinisk nytteverdi. Oslo: Senter for Medisinsk Metodevurdering, 2003

3. van Westreenen HL, Westerterp M, Bossuyt PMM et al. Systematic review of the staging performance of $18 \mathrm{~F}$-fluorodeoxyglucose PET in esophageal cancer. J Clin Oncol 2004: 22: 3805-12.

4. Meyers BF, Downey RJ, Decker PA et al. The utility of PET in staging of potentially operable carcinoma of the thoracic esophagus: results of the American Oncology Group Z0060 trial. J Thorac Cardiovasc Surg 2007; 133: 738-45.

5. Højgård L. Are health technology assessments a reliable tool in the analysis of the clinical value of PET in oncology? Eur J Nucl Med Mol Imaging 2003; 5: 637-41.

6. Anbefalinger for udbygning af PET og FDG produktion. København: Sundhedsstyrelsen, 2002

7. Kristensen FB, Adams E, Briones E et al. Health technology assessment of PET in oncology: re Eur J Nucl Med Mol Imaging 2003; 30: 637-41. Leserbrev. Eur J Nucl Med Mol Imaging 2004; 31: 295-7. 